\title{
Wild food plants and fungi used by Ukrainians in the western part of the Maramureş region in Romania
}

\author{
Łukasz Łuczaj1*, Kinga Stawarczyk¹, Tomasz Kosiek², Marcin Pietras ${ }^{3}$, Anna Kujawa ${ }^{4}$ \\ 1 Department of Botany, Institute of Applied Biotechnology and Basic Sciences, University of Rzeszów, Werynia 502, 36-100 Kolbuszowa, Poland \\ ${ }^{2}$ Intitute of History, Faculty of Sociology and History, University of Rzeszów, Al. Rejtana 16c, 35-959 Rzeszów, Poland \\ ${ }^{3}$ Institute of Dendrology, Polish Academy of Sciences, Parkowa 5, 62-035 Kórnik, Poland \\ ${ }^{4}$ Institute for Agricultural and Forest Environment, Polish Academy of Sciences, Research Station in Turew, Turew, Szkolna 4, 64-000 Kościan, Poland
}

\begin{abstract}
Wild food and fungi use in the countryside has always been an important part of human-nature relationships. Due to social changes in most rural areas of Europe this part of traditional ecological knowledge is shrinking. The aim of our study was to record the use of wild foods and plants among the Ukrainian (Carpatho-Rusyns) minority in the western part of Romanian Maramureş. We carried out 64 interviews in two villages. Voucher specimens were collected and DNA barcoding was used to identify most fungi taxa. We recorded the use of 44 taxa of plants altogether (including 8 taxa used only for herbal teas) and 24 taxa of fungi. On average 7.7 species of plants and 9.7 species of fungi were listed per interview. Edible fungi are thus an important part of local cuisine and they are eagerly gathered by everyone. The use of a few woodland bracket fungi is worth pointing out. No signs of degeneration of this knowledge were observed. Wild fruits are less collected now and wild greens are rarely collected nowadays. This pattern is typical of many places in Central Europe.
\end{abstract}

Keywords: ethnobotany; ethnomycology; mycophilous; Romania; Ukraine

\section{Introduction}

South-Eastern Europe is, due to a combination of historical, political and biological factors, a hotspot of biocultural diversity in Europe [1]. This also applies to Romania, a country with sizable ethnic minorities and a well-preserved rural culture [2,3]. The particular position of Romania as a place where the relics of ancient customs and traditions abound was emphasized by the famous anthropologist Mircea Eliade [4].

Romania was the subject of several ethnographic studies concerning plant and fungi use in the 19th and 20th centuries, but these works only concerned the Romanian and Hungarian population (for summary see [5-7]). In the past few years, modern ethnobotanical studies have been carried out in Romania. They were focused on ethnic minorities such as Hungarians [7-11], Poles [12,13], Italians [14] and Tartars [15].

In this article we would like to look at an aspect of the ethnobotany of Ukrainians, who are the fourth largest ethnic group in Romania (after Romanians, Hungarians and Roma). No ethnobotanical research has yet been carried out among

\footnotetext{
* Corresponding author. Email: lukasz.luczaj@interia.pl
}

Handling Editor: Beata Zagórska-Marek the Ukrainians of Romania. What is more, to this date, only one ethnobotanical paper (using a modern approach with a large number of informants) has been published concerning any Ukrainian population in Europe [16].

Knowledge of wild food plants and fungi used to be an important part of rural culture in Europe. Although on an everyday basis these items constituted only a small part of calorie intake, they provided an important diversification of a diet based on a few staples, provided a source of vitamins, proteins and carbohydrates, and were crucial for the survival of people during times of famine or spring-time food shortages [17].

Several studies on wild food plants in Eastern and SouthEastern Europe have been published recently (e.g., [18-32]). They include reviews of older ethnographic literature and local field studies. However, no information is available concerning wild foods in the Maramureş region of Romania, hence the documentation of this domain was the aim of our study.

\section{Material and methods}

Ukrainians are the third largest ethnic minority in Romania (after Hungarians and Roma). According to the Romanian census of 2011 they number 51703 people, making up 
$0.3 \%$ of the total population of the country [33]. Ukrainians claim that the number is actually 250 000-300 000 [34]. Over $60 \%$ of all Romanian Ukrainians live in Maramureş County $[34,35]$, where they constitute $6.8 \%$ of the population. This group of Ukrainians mainly inhabits an area directly adjacent to the Ukrainian border. They found themselves divided between two countries (Romania and Czechoslovakia) after the fall of the Austro-Hungarian Empire in which Maramureş was a Hungarian administrative region [36]. After World War II the Czechoslavakian part of Maramureş was taken over by the Soviet Ukrainian Republic and is now a part of the Republic of Ukraine. In Romania Ukrainians form a majority around the town of Sighetu Marmației, although their villages are interspersed with Hungarian and Romanian settlements. The Ukrainian villages in Maramureş can be seen as the ragged southwestern edge of the whole Ukrainian speaking area. Some scholars, historians, ethnologists and local politicians distinguish a separate nation called Carpatho-Rusyns to differentiate the mountain Ukrainian populations in Slovakia, Poland, Romania and the Ukrainian Carpathians from the lowland Ukrainian nation [35,37]. This is a controversial point which we are not going to discuss in this article, hence we simply refer to the local population as "Ukrainian". Most of the Ukrainian villages in Maramureş were settled around the 14th century, probably from various parts of the Carpathian Mountains range [38,39].

In this study we researched the two largest lowland Ukrainian villages from the Tisa valley - Remeți (with 2478 inhabitants, data from 2011 [40]) and Lunca la Tisa (1030 inhabitants [41]; Fig. 1). The real population number is now much lower than that given in the statistics, due to the emigration to Western and Southern Europe. It is commonly believed that the origin of these two villages is different. Remeți people are locally called Hajnali, whereas some ethnographers classify the people from Lunca as belonging (with a few other villages further east) to the Hutsul ethnographic group, though this identity is not claimed by the actual population $[35,42]$.

Most people make a living from agriculture, work in Sighetu, or work abroad. Small-scale agriculture is well developed here. Most people grow their own staples (maize, wheat, potatoes, etc.), vegetables and fruits, and produce their own fruit brandy. They regained private land collectivized in the Communist period. Private pastures are managed communally using hired shepherds. The pastures located above the villages create an intrinsic mosaic of grassland, orchards and small-scale woodland, in some places turning into woodland meadows. The area has a very high plant diversity represented by riparian, ruderal, meadow, pasture and ancient woodland vegetation within a short walk of the village. Most forests near the village are deciduous, mixed with oak (Quercus spp.) and hornbeam (Carpinus betulus), then, higher up, dominated by beech (Fagus sylvatica).

The research was carried out following the American Anthropological Association Code of Ethics [43] and the International Society of Ethnobiology Code of Ethics [44]. Data were collected mainly using the free listing method, accompanied by participant observation informal walks with selected key informants. The research took place in November 2012, October 2013, and May and August 2014.

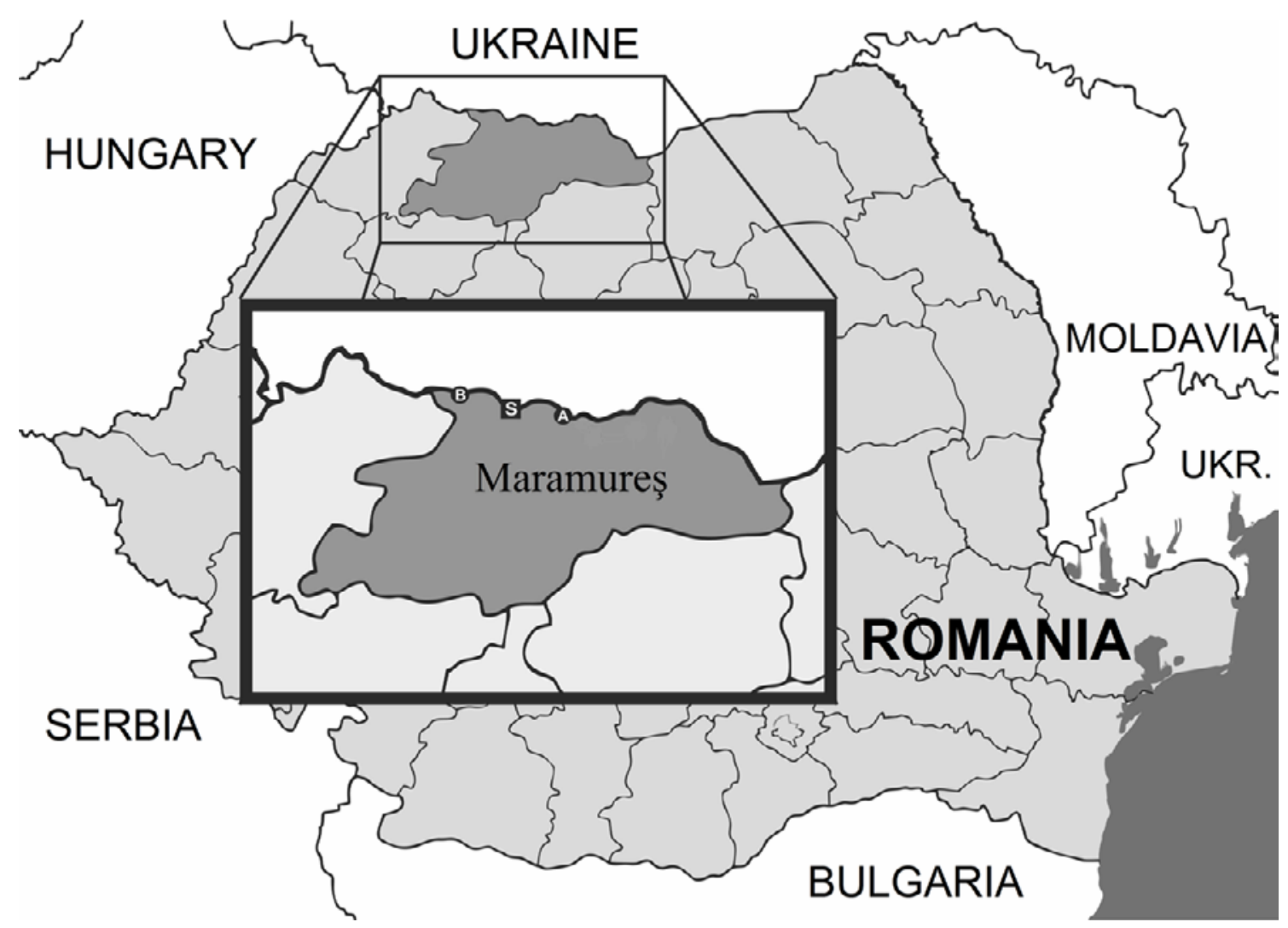

Fig. 1 Study area. A - Lunca la Tisa, B - Remeți, S - Sighetu Marmației, the nearest local town and market where mushrooms are sold. 
Interviews were carried out in the local dialect of Ukrainian. The interviews were carried out in two villages: Remeți (26 interviews) and Lunca la Tisa (40 interviews). Both villages are of nearly pure Ukrainian ethnicity. In Lunca people of the Orthodox denomination predominate, whereas Remeți is divided between Orthodox and two Neo-Protestant groups.

Participants were approached outside, during their farm work, or were pre-selected from among the knowledgeable informants (facilitated by the fact that T.K. had previously spent a few months living in Remeți, and K.S. had relatives living in Lunca). Altogether, 64 free listing questionnaires were obtained, mainly from middle-aged and elderly inhabitants. This included 52 single informants and 12 interviews with 2 or 3 people (altogether 74 people: 32 women, 41 men). Both the mean and median age of informants was 56.5 , with the oldest informant aged 89 and the youngest 26 .

The participants were asked their age and places of origin and habitation. Then they were asked the following questions:

1. What wild mushrooms have you collected?

2. What wild fruits have you collected?

3. What wild vegetables have you collected?

4. What wild roots have you collected?

Plants used as everyday infusions were also included if they were mentioned by the respondents, when used not with a strictly medical aim but drunk as so called "recreational tea" [45].

Voucher specimens were collected and deposited in the herbarium of the Faculty of Biology of Warsaw University (WA). Plant names used are consistent with The Plant List [46]. Most fungi specimens were successfully identified using the DNA barcoding technique $[47,48]$. Fungal DNA was extracted from a small part of each fruit body using Plant and Fungi DNA Purification Kit (Eurx), following standard protocol. The PCR cocktail consisted of $4 \mathrm{ml}$ DNA extract, $0.5 \mathrm{ml}$ each of the primers (ITS5 and ITS4 in $10 \mathrm{nmol}$ concentration) and $5 \mathrm{ml}$ Type-it Microsatellite PCR Kit (Qiagen). PCR was carried out using the following thermocycling conditions: an initial $15 \mathrm{~min}$ at $95^{\circ} \mathrm{C}$, followed by 35 cycles at $95^{\circ} \mathrm{C}$ for $30 \mathrm{~s}, 55^{\circ} \mathrm{C}$ for $30 \mathrm{~s}, 72^{\circ} \mathrm{C}$ for $1 \mathrm{~min}$, and a final cycle of $10 \mathrm{~min}$ at $72^{\circ} \mathrm{C}$. PCR products were estimated by running $5 \mathrm{ml}$ DNA amplicon on 1.5\% agarose gel for $30 \mathrm{~min}$. The PCR products were sequenced using ITS4 primers at the Laboratory of Molecular Biology of Adam Mickiewicz University (Poznań). The obtained sequences were verified visually on chromatograms using BIOEDIT. Nuclear ITS sequences obtained in this study are deposited in GenBank [49], with the accession numbers listed in Tab. 1.

\section{Results}

Altogether, 44 species of wild food and herbal tea plants (36 species if herbal teas are excluded) and 24 mushroom taxa were recorded as used nowadays or in the recent past (since World War II) in the area (Tab. 2, Tab. 3). Among the listed species are 10 species whose leaves are used for raw salads or cooked dishes, 17 species with edible fruits, and 12 species whose leaves, shoots or flowers are used for everyday herbal teas. On average, 17.4 species (median $=$ 17, minimum 6, maximum 36) were listed per interview: 9.7 species of fungi (maximum 18), 4.4 species of fruits (median 4.5, maximum 11), 1.7 species of wild vegetables (median 1, maximum 6), 0.7 species used as herbal teas (median 0 ), 0.5 species with edible flowers (median 0 ) and 0.4 species with edible roots (median 1).

Four of the most commonly used wild food plant species were fruits: Rubus idaeus, Rubus spp. (subgenus Rubus), Vaccinium myrtillus and Fragaria vesca. The next few places in the frequency rank were occupied by wild greens (Chenopodium album, Rumex acetosa and Urtica dioica) and fruits (Rosa canina, Prunus avium and P. spinosa) interchangeably.

The most often used wild foods in the studied villages are mushrooms. They are eagerly collected by nearly everyone and everyone mentioned mushrooms in their free list. They are eaten both fresh and preserved. The most common preparation technique is frying with onions. They are also added to soups and sauces. Zakuska is a popular sauce made of fried

Tab. 1 Molecular identification of mushroom samples analyzed in this study and GenBank accession numbers for nrITS sequences (see Tab. 3 for full names including authority).

\begin{tabular}{|c|c|c|c|c|c|}
\hline Sample No. & Identification & Best match & $E$-value & Similarity (\%) & Accession numbers \\
\hline 1 & Lactifluus glaucescens & Lactifluus glaucescens & 0.0 & 99 & KP967537 \\
\hline 2 & Ramaria flavescens & Ramaria flavescens & 0.0 & 99 & KР967538 \\
\hline 3 & Russula cyanoxantha & Russula cyanoxantha & 0.0 & 97 & KP967539 \\
\hline 4 & Russula heterophylla & Russula heterophylla & 0.0 & 99 & KP967540 \\
\hline 5 & Leccinum pseudoscabrum & Leccinum pseudoscabrum & 0.0 & 99 & KР967541 \\
\hline 6 & $\begin{array}{l}\text { Ramaria sp. (Ramaria cf } \\
\text { flavigelatinosa) }\end{array}$ & Ramaria flavigelatinosa & 0.0 & 96 & KP967542 \\
\hline 8 & Macrolepiota procera & Macrolepiota procera & 0.0 & 99 & KР967543 \\
\hline 10 & Russula virescens & Russula virescens & 0.0 & 99 & КР967544 \\
\hline 31 & Lactarius controversus & Lactarius controversus & 0.0 & 99 & KP967545 \\
\hline 32 & Russula medullata & Russula medullata & 0.0 & 99 & KP967546 \\
\hline 33 & Entoloma clypeatum & Entoloma clypeatum & 0.0 & 98 & KP967547 \\
\hline
\end{tabular}


Tab. 2 Plants used in food contexts in the study area.

\begin{tabular}{|c|c|c|c|c|c|}
\hline Scientific name & $\begin{array}{l}\text { Local name (LU - Lunca la Tisa; } \\
\text { RE - Remeți) }\end{array}$ & Part used & $\begin{array}{l}\text { Use reports } \\
\qquad N=66\end{array}$ & Use & $\begin{array}{l}\text { Voucher number } \\
\text { (starting from } \\
\text { WA00000) }\end{array}$ \\
\hline Achillea millefolium $\mathrm{L}$. & мурашчуннік, мурашчунник & $\mathrm{fl}$ & 7 & tea & 46934 \\
\hline Allium spp. & дикий часнок, дика цибуля & 1 & 3 & snack & - \\
\hline $\begin{array}{l}\text { Armoracia rusticana P. Gaertn., } \\
\text { B.Mey. \& Scherb. }\end{array}$ & хрін & $\mathrm{rt}$ & 9 & spice for a salad & 46954 \\
\hline Betula pendula Roth & береза & sap & 9 & raw beverage & 46943 \\
\hline Carum carvi L. & дикий кмин & fr & 8 & tea, cabbage dishes & 46936 \\
\hline Centaurium erythraea Rafn. & цинторія & $\mathrm{fl}$ & 2 & tea & - \\
\hline Chenopodium album $\mathrm{L}$. & натина, лобода & 1 & 18 & boiled side-dish & 46942 \\
\hline Cornus mas $\mathrm{L}$. & корн, кизил & fr & 2 & raw snack & 46929 \\
\hline Corylus avellana $\mathrm{L}$. & горішки ліскові & $\mathrm{fr}$ & 15 & raw snack & 46925 \\
\hline Crataegus rhipidophylla Gand. & глуг & fr & 1 & tea & 46940 \\
\hline Fagus sylvatica $\mathrm{L}$. & жир & fr, 1 & 7 & raw children's snack & 46944 \\
\hline Fallopia japonica (Houtt.) Ronse Decr. & RE: бамбус, бамбусиня & 1 & 4 & sarma wrapping & 46960 \\
\hline Fragaria vesca $\mathrm{L}$. & ягоди & fr & 30 & raw & 46948 \\
\hline Helianthus tuberosus $\mathrm{L}$. & пічованіе, пічовані & $\mathrm{t}$ & 13 & $\begin{array}{l}\text { raw snack, formerly } \\
\text { also as emergency } \\
\text { staple }\end{array}$ & 46953 \\
\hline Hypericum perforatum $\mathrm{L}$. & кровник, звіробій & $\mathrm{fl}$ & 8 & tea & 46933 \\
\hline Malus sp. & ябука & fr & 5 & fruit brandy & - \\
\hline $\begin{array}{l}\text { Matricaria suaveolens Koch \& } \\
\text { Matricaria chamomilla L. }\end{array}$ & LU: романечка, RE: романиця & $\mathrm{fl}$ & 6 & tea & 46935 \\
\hline Origanum vulgare $\mathrm{L}$. & материнка & $\mathrm{fl}$ & 3 & tea & 46932 \\
\hline Oxalis stricta $\mathrm{L}$. and O. acetosella $\mathrm{L}$. & капуста заецова & 1 & 1 & raw snack & 46941 (str) \\
\hline Picea abies (L.) H. Karst. & $\begin{array}{l}\text { ялина (tree), чатиня (young } \\
\text { twigs) }\end{array}$ & 1 & 14 & $\begin{array}{l}\text { young twigs covered } \\
\text { in syrup - medicinal } \\
\text { snack }\end{array}$ & 46949 \\
\hline Polypodium vulgare $\mathrm{L}$. & солодиш & $\mathrm{rh}$ & 2 & raw snack (obsolete) & - \\
\hline Prunus avium L. & дикі черешні & $1, \mathrm{p}$ & 17 & $\begin{array}{l}\text { fruits - raw, fruit } \\
\text { brandy; fruit petiole } \\
\text { - tea (believed to help } \\
\text { kidneys) }\end{array}$ & 46930 \\
\hline Prunus spinosa $\mathrm{L}$. & тер, терень & fr & 16 & raw snack & 46945 \\
\hline $\begin{array}{l}\text { Quercus robur L., Q. petraea (Matt.) } \\
\text { Liebl. }\end{array}$ & жолуді, горішки дубове & fr & 5 & $\begin{array}{l}\text { formerly a famine } \\
\text { admixture to staple } \\
\text { foods }\end{array}$ & $\begin{array}{l}46946 \text { (ro), } 46959 \\
\text { (pe) }\end{array}$ \\
\hline Ranunculus ficaria L. & LU: дикий салат, ліболабо & 1 & 7 & soups, boiled side-dish & - \\
\hline Robinia pseudoacacia L. & LU: акація, акац & $\mathrm{fl}$ & 5 & raw snack & 46957 \\
\hline Rosa canina $\mathrm{L}$. & гечи-печи, гечи & fr & 25 & jam, tea & 46938 \\
\hline Rubus fruticosus L. agg. \& R. caesius $\mathrm{L}$. & черниця & fr & 48 & raw snack, jam & $\begin{array}{l}46926,46958(\mathrm{fr}) \\
46927(\mathrm{cae})\end{array}$ \\
\hline Rubus idaeus L. & малина & fr & 50 & raw snack, jam & 46947 \\
\hline Rumex patientia $\mathrm{L}$. & щава & 1 & 5 & $\begin{array}{l}\text { boiled side-dish, sarma } \\
\text { wrapping }\end{array}$ & 46950 \\
\hline Rumex acetosa L. \& R. acetosella L. & LU: магріш, квасок, RE: квасник & 1 & 27 & raw snack, soup & $\begin{array}{l}46937 \text { (-osa), } \\
46951 \text { (-ella) }\end{array}$ \\
\hline Sambucus nigra $\mathrm{L}$. & бзина & $\mathrm{fl}$ & 13 & tea & 46955 \\
\hline Taraxacum sect. Ruderalia sp. pl. & хрищатник, кульбаба & 1 & 11 & $\begin{array}{l}\text { raw salad, boiled side- } \\
\text { dish }\end{array}$ & - \\
\hline Thymus serpyllum L. s.l. & чабрик & $\mathrm{fl}$ & 4 & $\begin{array}{l}\text { tea, spice for home- } \\
\text { made sausage }\end{array}$ & 46939 \\
\hline
\end{tabular}


Tab. 2 (continued)

\begin{tabular}{|c|c|c|c|c|c|}
\hline Scientific name & $\begin{array}{l}\text { Local name (LU - Lunca la Tisa; } \\
\text { RE - Remeți) }\end{array}$ & Part used & $\begin{array}{l}\text { Use reports } \\
\qquad N=66\end{array}$ & Use & $\begin{array}{l}\text { Voucher number } \\
\text { (starting from } \\
\text { WA00000) }\end{array}$ \\
\hline $\begin{array}{l}\text { Tilia cordata Mill., T. platyphyllos } \\
\text { Mill. }\end{array}$ & лепа, ліпа, липа & $\mathrm{fl}$ & 7 & tea & - \\
\hline Tussilago farfara $\mathrm{L}$. & подбіл & 1 & 3 & sarma wrapping (rarely) & 46928 \\
\hline Urtica dioica $\mathrm{L}$. & кропива, жалива & 1 & 16 & soup, boiled side-dish & 46961 \\
\hline Vaccinium myrtillus L. & афини & fr, 1 & 34 & $\begin{array}{l}\text { raw, jam, fruit brandy; } \\
\text { twigs for tea }\end{array}$ & 46931 \\
\hline Vaccinium vitis-idaea $\mathrm{L}$. & афини черлене, мирішоре & fr, 1 & 5 & raw; twigs for tea & 46952 \\
\hline Viburnum opulus L. & калина & fr & 7 & $\begin{array}{l}\text { raw after frosts - } \\
\text { collected straight from } \\
\text { the bush or kept dried } \\
\text { in a hay stack }\end{array}$ & 46956 \\
\hline
\end{tabular}

$\mathrm{fl}$ - flowers or flowering tops; fr - fruits; 1 - leaves or young shoots; $\mathrm{p}$ - fruit petioles; rh - rhizomes; rt - roots; $\mathrm{t}$ - tubers

Tab. 3 Wild food fungi used in the study area. Classification follows Species Fungorum (http://www.speciesfungorum.org).

\begin{tabular}{|c|c|c|c|}
\hline Scientific name & Local name; LU - Lunca la Tisa, Re - Remeți & $\begin{array}{l}\text { Use reports } \\
\qquad N=66\end{array}$ & $\begin{array}{l}\text { Voucher No. } \\
\text { (starting from } \\
\text { WA00000) }\end{array}$ \\
\hline Agaricus sp. & LU: шампінйони, шампйони, RE: печериця & 10 & - \\
\hline Armillaria ostoyae (Romagn.) Herink & LU: геби, RE: пудпіки & 47 & 51001 \\
\hline Boletus edulis Bull. & $\begin{array}{l}\text { LU: товстокоренцібілухи, гриби [two kinds: дубові - “oak } \\
\text { ones”, смерекові - “spruce ones"]; RE: білухи }\end{array}$ & 66 & 51002 \\
\hline Cantharellus cibarius Fr. & лисички & 52 & - \\
\hline Entoloma clypeatum (L.) P. Kumm. & LU: пудпіки; RE: пудсадники & 28 & 51003 \\
\hline $\begin{array}{l}\text { Lactifluus glaucescens (Crossl.) Verbeken \& } \\
\text { Lactarius controversus Pers. }\end{array}$ & LU: білі, RE: біляки, горкині & 56 & $\begin{array}{l}51004 \text { (L. glauc.), } \\
51021 \text { (L. contr.) }\end{array}$ \\
\hline Lactarius volemus (Fr.) Fr. & соловішка & 7 & - \\
\hline Laetiporus sulphureus (Bull.) Murrill & RE: корбани & 7 & 51005 \\
\hline Leccinum scabrum (Bull.) Gray & козарі & 45 & 51006,51007 \\
\hline $\begin{array}{l}\text { Leccinum aurantiacum (Bull.) Gray \& L. versipelle } \\
\text { (Fr. \& Hök) Snell }\end{array}$ & LU: тополяки, RE: черленюхи & 56 & $\begin{array}{l}51008 \text { (L. aur.), } \\
51009 \text { (L. ver.) }\end{array}$ \\
\hline Leccinum pseudoscabrum (Kallenb.) Šutara & пудлісники & 20 & 51010 \\
\hline Lycoperdon, Bovista or/and Calvatia & поргавка, порчавка & 8 & - \\
\hline Macrolepiota procera (Scop.) Singer & LU \& RE: кучмо гомбо, LU: омбрели & 38 & 51011,51012 \\
\hline Pleurotus cf ostreatus (Jacq.) P. Kumm. & гливи & 29 & - \\
\hline Polyporus squamosus (Huds.) Fr. & LU: пистряки, RE: пистрики & 16 & 51013 \\
\hline $\begin{array}{l}\text { Ramaria flavescens (Schaeff.) R.H. Petersen \& R. } \\
\text { cf flavigelatinosa Marr \& D.E. Stuntz (?) }\end{array}$ & LU: ряска, RE: перстика & 33 & $\begin{array}{l}51014 \text { (R. flaves.) } \\
51015 \text { (R. flavig.) }\end{array}$ \\
\hline $\begin{array}{l}\text { Russula virescens (Schaeff.) Fr., R. cyanoxantha } \\
\text { (Schaeff.) Fr., R. heterophylla (Fr.) Fr., } R \text {. medullata } \\
\text { Romagn. }\end{array}$ & mainly: голубінки, also: суроядка, сироїжка & 66 & $\begin{array}{l}51016 \text { (R. vires.), } \\
51017 \text { (R. cyan.), } \\
51018 \text { (R. heter.), } \\
51016 \text { (R. med.) }\end{array}$ \\
\hline Xerocomellus chrysenteron (Bull.) Šutara & LU: пітух, RE: потячник, жултюх & 8 & 51020 \\
\hline
\end{tabular}


mushrooms, onions, tomatoes and paprika. It is a side-dish, which is often pasteurized for winter. Mushrooms are stored in a variety of ways. They are frozen (now a most common preparation technique), pasteurized after boiling, pickled in a brine of vinegar, salt, sugar, bay leaf and black pepper, or lactofermented. The most commonly used mushroom, and most highly regarded is bolete Boletus edulis, mentioned by all respondents. Another taxon mentioned by everyone was Russula. Other frequently used taxa include scabrous bolete Leccinum spp., milk-caps (Lactifluus glaucescens and Lactarius controversus as one folk taxon), chanterelle Cantharellus cibarius, honey fungus Armillaria ostoyae, parasol mushroom Macrolepiota procera, Ramaria spp., oyster mushroom Pleurotus ostreatus and Entoloma clypeatum.

Milk caps (Lactifluus glaucescens and Lactarius controversus) are treated as a delicacy due to their strongly peppery taste. This is also why they are not mixed with other species. The gills of these milk-caps are scraped off before use and only the remaining part of the cap is fried directly in the frying pan (with onions). Another species with an interesting use is Lactarius volemus, which is eaten raw.

Most edible fleshy fruits from trees and shrubs are collected in the area. Most commonly these are blackberry (Rubus spp.), bilberry (Vaccinium myrtillus), wild strawberry (Fragaria vesca), wild cherry (Prunus avium) and raspberry (Rubus idaeus). Fruits are usually eaten raw, made into jams or distilled into fruit brandy. Wild fruits have a secondary role as the villages and the land around them are full of cultivated fruit plants (mainly apples, pears, plums and grapevine).

Wild greens are rarely collected nowadays, they were more commonly eaten in the 1960s and earlier. Only a few species have been used, i.e., commonly lamb's quarters Chenopodium album, nettle Urtica dioica, sorrel Rumex acetosa and more rarely lesser celandine Ranunculus ficaria. The greens are boiled and/or fried to make a side-dish or soup.

There are only two wild plants whose underground organs are commonly collected. The tubers of Jerusalem artichoke (Helianthus tuberosus), now still widely eaten raw as a snack, but in the past also baked in the stove. The roots of horseradish (Artemisia rusticana) grows in a semi-domesticated state made into salad. The third species, mentioned only by two older informants from Lunca, are the sweet rhizomes of a woodland fern, polypody (Polypodium vulgare), which used to be eaten as a snack by children.

\section{Discussion}

The proportions of different categories of wild foods collected in the study area is very typical for Central Europe as a whole. The largest and most appreciated categories are mushrooms, followed by fruits. Wild green vegetables constitute a minor source of food. A nearly identical pattern can be observed in national-scale reviews for Poland [18,50], the Czech Republic [51], Hungary [20], Estonia [19], Slovakia [21] and Sweden [22]. Although the lists of wild greens are long, the use of most species is extinct or concerns small territories, whereas only a few species of wild fruits are gathered commonly and quoted in most local studies listed in those reviews. The plant taxa eaten most commonly in the study area are nearly the same as the taxa eaten most commonly in other northern Slavic countries and other above-mentioned countries. For example seven of the wild food plants with the highest number of citations in our study were among the eight most commonly used wild food plants in Poland [18]. Local studies in a hilly area of Austria and in western Ukraine showed a similar pattern, with fruits and fungi the dominant kind of wild food gathered by locals [16,52].

The slight importance of wild greens recorded here is very characteristic of other northern Slavic territories and Eastern and Northern European countries [17-22], where the use of wild greens is mainly limited to Rumex spp., Chenopodium album and Urtica dioica, although in this area some more variety in the use of wild edible leaves can be observed (for instance the former use of Ranunculus ficaria for soups or wrapping sarma with the leaves of Reynoutria japonica). Interestingly, we did not record use of the fruits of elder (Sambucus nigra), which is practiced in neighboring countries (e.g., $[16,18,44]$, though the flowers are used to make beverages in the study area.

The most often used mushroom taxa (Boletaceae, Russula, Lactifluus, Lactarius, Cantharellus) in the study area are identical to those used in other parts of the northern Slavic area [50,53-55]. The number of locally used taxa (16 folk genera containing 24 scientific species) is similar to other local ethnomycological studies from Central Europe compared for example to 17 folk taxa containing 28 scientific species used in three studied villages in SE Poland or 15 taxa recorded in the Roztochya region in western Ukraine. It is however surprising that locals do not gather Suillus spp. and Lactarius sect. Deliciosi - widely known and used in Poland, Ukraine, Belarus and Russia (e.g., [16,53-55]). This may stem from the fact that their host tree species, Pinus sylvestris, Larix spp. and Abies alba are hard to find in this area and Picea abies (a symbiotic tree for Lactarius deterrimus) is not so widespread either.

Out of the fifteen mushroom taxa used in the Roztochya region in western Ukraine, ten are used in our study area. The discrepancy probably stems from the different mycobiota found in the two places, or at least the differences inabundance of particular taxa. On the other hand cultural factors may also be partly responsible. For instance, a striking feature of the local repertoire of mushrooms used is a considerable list of taxa growing on tree trunks, such as Polyporus squarrosus, oyster mushrooms Pleurotus spp., and Laetiporus sulphureus. The knowledge of Entoloma clypeatum is also worth emphasizing. This is a species growing in grasslands among Rosaceae fruit trees (associated mainly with plums in the study area) rarely reported as traditionally used in Europe (but eaten for example by Croats [56], Hungarians [57]; and Ukrainians $[53,58])$ and easily confused with some highly toxic taxa.

An interesting feature of the local cuisine is the use of Lactifluus glaucescens, a species with a strong peppery taste, highly appreciated by the locals. Its use has not yet been recorded by ethnomycological works yet, but this probably stems from the fact that it was usually not distinguished from the similar L. piperatus. A clear difference between 
the two species was confirmed by genetic studies [59]. The latter species is used for food in many parts of Poland $[53,54]$, Hungary [57] and Russia [55]. This group of milkcaps is also commonly collected in other parts of Romania $[6,57]$. It is not unlikely that L. piperatus also occurs in the study area and is not distinguished from the former species. Another species not distinguished from L. glaucescens is Lactarius controversus gathered in the study area. Similarly to L. glaucescens it has not been reported in ethnomycological studies as being used for food. The collection of data on the gathering and consumptions of different species of Lactarius and Lactifluus can be one of the aims of European ethnomycology as in some countries a large number of species from

\section{Acknowledgments}

We are very grateful to all the people of Maramureș who willingly took part in the study, particularly the Sofineți family from Lunca and Misa Pop from Remeți. The research was financed by the Institute of Applied Biotechnology and Basic Sciences, University of Rzeszów.

\section{Authors' contributions}

The following declarations about authors' contributions to the research have been made: interviews were performed by $Ł Ł, ~ K S$ and TK; morphological identification of fungi: AK; DNA analysis: MP; plant identification and writing the first draft: $Ł €$. All the authors took part in writing the final version.

\section{Competing interests}

The following declarations about authors' competing interests have been made: $Ł \mathrm{~L}$ I am an associate editor of the Acta Societatis Botanicorum Poloniae journal; other authors: no competing interests.

\section{References}

1. Pieroni A, Quave CL, editors. Ethnobotany and biocultural diversities in the Balkans: perspectives on sustainable rural development and reconciliation. New York, NY: Springer; 2014

2. Horváth I, Scacco A. From the unitary to the pluralistic: fine-tuning minority policy in Romania. In: Bíró AM, Kovács P, editors. Diversity in action: local public management of multi-ethnic communities in Central and Eastern Europe. Budapest: Local Government and Public Service Reform Initiative. Open Society Institute; 2001. p. 241-271.

3. Ram MH. Romania: from laggard to leader? In: Rechel B, editor. Minority rights in Central and Eastern Europe. London: Routledge, Taylor \& Francis Group; 2009. p. 180-194.

4. Eliade M. De la Zalmoxis la Genghis-han. Paris: Payet; 1970.

5. Borza A, Beldie A. Dictionar etnobotanic. Bucharest: Editura Academiei Republicii Socialiste România; 1968.

6. Butură V. Enciclopedie de etnobotanică românească. Bucharest Editura Științifică și Enciclopedică; 1979.

7. Péntek J, Szabó A. Ember és növényvilág: kalotaszeg növényzete és népi növényismerete. Bucharest: Kriterion; 1985.

8. Papp N, Birkás-Frendl K, Farkas Á, Pieroni A. An ethnobotanical study on home gardens in a Transylvanian Hungarian Csángó village (Romania). Genet Res Crop Evol. 2013;60(4):1423-1432. http://dx.doi. org/10.1007/s10722-012-9930-7

9. Papp N, Czégényi D, Hegedüs A, Morschhauser T, Quave CL, Cianfaglione K, et al. The uses of Betula pendula Roth among Hungarian Csángós and Székelys in Transylvania, Romania. Acta Soc Bot Pol. 2014;83(2):113-122. http://dx.doi.org/10.5586/asbp.2014.011

10. Papp N, Birkás-Frendl K, Bencsik T, Czégényi D. Ethnobotanical surveys in Transylvania: past, present and future. Bulletin of the Transilvania University of Braşov. Series II: Forestry - Wood Industry Agricultural Food Engineering. 2013;4(53):2-6

11. Kóczián G, Pintér I, Gál M, Szabó I, Szabó L. Etnobotanikai adatok Gyimesvölgyéből. Botanikai Közlemények. 1976;63(1):29-35. these related genera is used (e.g., in Spain, see [60,61], but this phenomenon is little documented.

\section{Conclusions}

Fungi are culturally more important than wild food plants for the studied population. Due to the large number of frequently used fungi taxa, the Ukrainians of Maramureş can definitely be described as a mycophilous community.

The use of wild fruits and greens for consumption is decreasing, a similar trend to that observed in other rural areas of Eastern Europe.

12. Kołodziejska-Degórska I. Mental herbals - a context-sensitive way of looking at local ethnobotanical knowledge: examples from Bukovina (Romania). Trames. 2012;16(3):287-301. http://dx.doi.org/10.3176/ tr.2012.3.04

13. Kołodziejska-Degórska I. Z czego "uwarić herbatę"? Dzikie rośliny jadane w polskich wsiach na południowej Bukowinie (Rumunia). In: Łuczaj Ł, editor. Conference proceedings "Dzikie rośliny jadalne zapomniany potencjał przyrody”; 2007 Sep 13; Przemyśl-Bolestraszyce. Bolestraszyce: Arboretum i Zakład Fizjografii w Bolestraszycach; 2008. p. 219-226.

14. Pieroni A, Quave CL, Giusti ME, Papp N. "We are Italians!”: the hybrid ethnobotany of a Venetian diaspora in eastern Romania. Hum Ecol. 2012;40:435-451. http://dx.doi.org/10.1007/s10745-012-9493-4

15. Pieroni A, Nedelcheva A, Dogan Y. Local knowledge of medicinal plants and wild food plants among Tatars and Romanians in Dobruja (south-east Romania). Genet Res Crop Evol. 2014;1-16. http://dx.doi. org/10.1007/s10722-014-0185-3

16. Stryamets N, Elbakidze M, Ceuterick M, Angelstam P, Axelsson R From economic survival to recreation: contemporary uses of wild food and medicine in rural Sweden, Ukraine and NW Russia. J Ethnobiol Ethnomed. 2015;11:53. http://dx.doi.org/10.1186/s13002-015-0036-0

17. Łuczaj Ł, Pieroni A, Tardío J, Pardo-de-Santayana M, Sõukand R, Svanberg I, et al. Wild food plant use in 21st century Europe: the disappearance of old traditions and the search for new cuisines involving wild edibles. Acta Soc Bot Pol. 2012;81(4):359-370. http:// dx.doi.org/10.5586/asbp.2012.031

18. Łuczaj Ł. Archival data on wild food plants used in Poland in 1948. J Ethnobiol Ethnomed. 2008;4(1):4. http://dx.doi. org/10.1186/1746-4269-4-4

19. Kalle R, Sõukand R. Historical ethnobotanical review of wild edible plants of Estonia (1770s-1960s). Acta Soc Bot Pol. 2012;81(4):271-281. http://dx.doi.org/10.5586/asbp.2012.033

20. Dénes A, Papp N, Babai D, Czúcz B, Molnár Z. Wild plants used for food by Hungarian ethnic groups living in the Carpathian Basin. Acta Soc Bot Pol. 2012;81(4):381-396. http://dx.doi.org/10.5586/ asbp. 2012.040

21. Łuczaj Ł. Ethnobotanical review of wild edible plants of Slovakia Acta Soc Bot Pol. 2012;81(4):245-255. http://dx.doi.org/10.5586/ asbp. 2012.030

22. Svanberg I. The use of wild plants as food in pre-industrial Sweden. Acta Soc Bot Pol. 2012;81(4):317-327. http://dx.doi.org/10.5586/ asbp.2012.039

23. Redžić S. Wild edible plants and their traditional use in the human nutrition in Bosnia-Herzegovina. Ecol Food Nutr. 2006;45(3):189-232. http://dx.doi.org/10.1080/03670240600648963

24. Łuczaj Ł, Köhler P, Pirożnikow E, Graniszewska M, Pieroni A, Gervasi T. Wild edible plants of Belarus: from Rostafiński's questionnaire of 1883 to the present. J Ethnobiol Ethnomed. 2013;9(1):21. http://dx.doi. org/10.1186/1746-4269-9-21

25. Redzić S. Use of wild and semi-wild edible plants in nutrition 
and survival of people in 1430 days of siege of Sarajevo during the war in Bosnia and Herzegovina (1992-1995). Coll Antropol. 2010;34(2):551-570

26. Łuczaj $Ł$, ZovkoKončić M, Miličević T, Dolina K, Pandža M. Wild vegetable mixes sold in the markets of Dalmatia (southern Croatia). J Ethnobiol Ethnomed. 2013;9(1):2. http://dx.doi. org/10.1186/1746-4269-9-2

27. Łuczaj $€$, Fressel N, Perković S. Wild food plants used in the villages of the Lake Vrana Nature Park (northern Dalmatia, Croatia). Acta Soc Bot Pol. 2013;82(4):275-281. http://dx.doi.org/10.5586/asbp.2013.036

28. Dolina K, Łuczaj $€$. Wild food plants used on the Dubrovnik coast (south-eastern Croatia) Acta Soc Bot Pol. 2014;83(3):175-181. http:// dx.doi.org/10.5586/asbp.2014.029

29. Łuczaj $Ł$. Changes in the utilization of wild green vegetables in Poland since the 19th century: a comparison of four ethnobotanical surveys. J Ethnopharmacol. 2010;128(2):395-404. http://dx.doi.org/10.1016/j. jep.2010.01.038

30. Nedelcheva A. An ethnobotanical study of wild edible plants in Bulgaria. Eurasia J Biosci. 2013;7:77-94. http://dx.doi.org/10.5053/ ejobios.2013.7.0.10

31. Redžić S, Ferrier J. The use of wild plants for human nutrition during a war: eastern Bosnia (Western Balkans). In: Pieroni C, Quave CL, editors. Ethnobotany and biocultural diversities in the Balkans. New York, NY: Springer; 2014. p. 149-182.

32. Łuczaj Ł. Brzozowy sok, "czeremsza" i zielony barszcz - ankieta etnobotaniczna wśród botaników ukraińskich. Etnobiologia Pol. 2012;2:15-22

33. Comunicat de presă privind rezultatele provizorii ale Recensământului Populatiei si Locuintelor - 2011, at the 2011 census site [Internet]. 2011 [cited $2015 \mathrm{Feb} 01$ ]; Available from: http://www.recensamantromania. ro/wp-content/uploads/2012/02/Comunicat_DATE_PROVIZORII_RPL_2011.pdf

34. King C, Melvin N, editors. Nations abroad: diaspora politics and international relations in the former Soviet Union. Boulder, CO: Westview Press; 1998.

35. Kosiek T. Czy w rumuńskim Maramureşzu mieszkają Huculi? Kilka uwag o kategorii Hucuł i Huculszczyzna w kontekście marmaroskim. In: Stęszewski J, Cząstka-Kłapyta J, editors. Kultura współczesnej Huculszczyzny. Kraków: Oficyna Wydawnicza "Wichry”; 2010. p. 45-62.

36. Magocsi PR, Pop I. Maramorosh. In: Magocsi PR, Pop I, editors. Encyclopedia of Rusyn history and culture. Toronto: University of Toronto Press Incorporated; 2002. p. 307.

37. Kosiek T. Ethnicity has many names. On the diverse acts of identification with the example of the Ukrainian minority in the Romanian region of Maramureş. In: Kuligowski W, Papp R, editors. Sterile and isolated? An anthropology today in Hungary and Poland, Poznań: Wydawnictwo TIPI; 2015. p. 111-127.

38. Kurelyak V. Hutsuly Maramoroshchyny i etnohrafichny problemy. Visnyk L'vivs'koho Universitetu - Seriya Heografichna. 1998;22:41-48.

39. Kurelyak V. Ukrayinci rumunskoyi Maramoroshchyny. Lviv: Vydavnychyj centr LNU im. Ivana Franka; 2001.

40. Remeți, Maramureș: de la Wikipedia, enciclopedia liberă [Internet]. 2015 [cited 2015 Apr 05]; Available from: https://ro.wikipedia.org/ wiki/Remeți,_Maramureș

41. Romanian companies: economic map of Lunca La Tisa (MM) [Internet]. 2015 [cited 2015 Apr 05]; Available from: http://www.romaniancompanies.eu/harta/maramures_lunca_la_tisa.htm

42. Len’o P. Etnokul'turni procesy v seredovyshchi ukrajinciv Maramoroshchyny. Narodna tvorchist ta etnohrafija. 2010;3:36-46.
43. American Anthropological Association Code of Ethics [Internet]. 2013 [cited 2015 Jan 10]; Available from: http://www.aaanet.org/issues/ policy-advocacy/upload/AAA-Ethics-Code-2009.pdf

44. International Society of Ethnobiology Code of Ethics (with 2008 additions) [Internet]. 2013 [cited 2015 Jan 10]; Available from: http:// ethnobiology.net/code-of-ethics/

45. Sõukand R, Quave CL, Pieroni A, Pardo-de-Santayana M, Tardío $\mathrm{J}$, Kalle R, et al. Plants used for making recreational tea in Europe: a review based on specific research sites. J Ethnobiol Ethnomed. 2013;9(1):58. http://dx.doi.org/10.1186/1746-4269-9-58

46. The Plant List: a working list of all plant species [Internet]. 2015 [cited 2015 Jan 10]; Available from: http://www.theplantlist.org/

47. Schocha CL, Seifertb K, Huhndorfc S, Robert V, Spouge JL, Levesque $\mathrm{CA}$, et al. Nuclear ribosomal internal transcribed spacer (ITS) region as a universal DNA barcode marker for Fungi. Proc Natl Acad Sci USA. 2012;109(16): 6241-6246. http://dx.doi.org/10.1073/pnas.1117018109

48. Begerow D, Nilsson H, Unterseher M, Maier W. Current state and perspectives of fungal DNA barcoding and rapid identification procedures. Appl Microbiol Biotechnol. 2010;87:99-108. http:// dx.doi/10.1007/s00253-010-2585-4

49. GenBank [Internet]. 2015 [cited 2015 Mar 27]; Available from: http:// www.ncbi.nlm.nih.gov/

50. Łuczaj $€$, Nieroda Z. Collecting and learning to identify edible fungi in southeastern Poland: age and gender differences. Ecol Food Nutr. 2011;50(4):319-336. http://dx.doi.org/10.1080/03670244.2011.586314

51. Šimková K, Polesný Z. Ethnobotanical review of wild edible plants used in the Czech Republic. J Appl Bot Food Qual. 2015;88:49-67.

52. Schunko C, Vogl CR. Organic farmers use of wild food plants and fungi in a hilly area in Styria (Austria). J Ethnobiol Ethnomed. 2010;6:17. http://dx.doi.org/10.1186/1746-4269-6-17

53. Łuczaj Ł, Köhler P. Grzyby w ankiecie Józefa Rostafińskiego (18501928) ogłoszonej w 1883 r. Etnobiologia Pol. 2014;4:7-54

54. Pawłowska J, Gajek J. Zbieranie i spożywanie grzybów z rodziny gołąbkowatych Russulaceae, mapa 314, Zbieranie i spożywanie grzyba mleczaj chrząstka Lactarius vellereus. In: Gajek J, editor. Polski atlas etnograficzny. Warszawa: Polska Akademia Nauk, Instytut Historii Kultury Materialnej; 1981.

55. Pirożnikow E. Rola pożywienia zbieranego z natury w życiu Polaków deportowanych do ZSRR w okresie drugiej wojny światowej. Etnobiologia Pol. 2014;4:135-172.

56. Grlić L. Naše samoniklo jestivo bilje. Zagreb: Poljoprivredni Nakladni Zavod; 1956.

57. Zsigmond G. The meanings and functions of mushrooms as food in Hungarian folk tradition. Acta Ethnographica Hungarica. 2010;55:115-138. http://dx.doi.org/10.1556/AEthn.55.2010.1.8

58. Zerova MY, Rozhenko GL Atlas s'edobnykh i yadovitykh gribov. Kiev: ??; 1988

59. de Crop E, Nuytinck J, van de Putte K, Lecomte M, Eberhardt U, Verbeken A. Lactifluus piperatus (Russulales, Basidiomycota) and allied species in Western Europe and a preliminary overview of the group worldwide. Mycol Prog. 2014;13(3):493-511. http://dx.doi. org/10.1007/s11557-013-0931-5

60. Rivera D, Obón C, Inocencio C, Heinrich M, Verde A, Fajardo J, et al. Gathered food plants in the mountains of Castilla-La Mancha (Spain): ethnobotany and multivariate analysis. Econ Bot. 2007;61(3):269-289.

61. Rodríguez JF, Sidera DB, Verde López A. El Género "Lactarius" en la provincia de Albacete. Sabuco: revista de estudios albacetenses. 2003;(4):5-33 